\title{
Potentials for savings in the Slovenian public enterprises and investments in infrastructure?
}

\author{
UDK: 330.526.34:330.322
}

\author{
Nevenka Hrovatin \\ University of Ljubljana, Faculty of Economics \\ nevenka.hrovatin@ef.uni-lj.si
}

\begin{abstract}
The author analyses the success rate and efficiency of Slovenian public sector companies in the course of their operations and looks into opportunities for savings and ways of attracting private investment in infrastructure. By reducing expenditures public companies achieve higher profits, from which the state in turn receives firstly, dividends as a form of budgetary revenue; and secondly, increased tax revenues, as public companies are not exempt from paying corporate income tax. By increasing the rate of return in public companies, the state therefore receives a larger slice of the budget pie on account of its two roles - as both owner and administrator, and as fiscal generator and provider. The author concludes that Slovenian companies cannot achieve identified possible savings without the efficient management of public sector companies. To this end at least two reforms should be introduced in Slovenia: firstly, the introduction of a system of contracts between the state and public sector companies on the meeting of specific pre-determined goals; and secondly, the establishment of a politically independent system of recruitment and appointment of managers based on professional references, and a management remuneration system tied to either the operating results achieved by said public companies or on the meeting of certain pre-determined goals set out in contracts between the state and public companies.
\end{abstract}

Key words: public enterprises, effectiveness, efficiency, public-private partnerships, public finance, Europe, Slovenia

JEL: L32, E6

\section{Introduction}

The aim of this paper is to analyse, based on literature review, how effective and efficient are Slovenian public enterprises in their operation and performance, what the room for cost reductions is and what the possibilities to 


\section{Nevenka Hrovatin \\ Potentials for savings in the Slovenian public \\ enterprises and investments in infrastructure?}

attract private funds into infrastructure financing are. If there are potentials for cost savings, public enterprises could earn higher profits, which could increase budget income in two ways, first the government gets higher income as the owner and second, it collects higher taxes since public enterprises are also obliged to pay corporate taxes. This means that by increasing the profitability of public enterprises the government gets higher budget revenues acting in two roles: as an owner and in its fiscal function. On the other hand, lowering of the costs may enable the fall in prices of products and services. This will result in the higher disposable income of users, which will stimulate the aggregate demand by higher spending and will enhance the economic growth.

The Slovenian government has been running the project on the modernisation of Slovenian public administration for several years, but it does not incorporate the Slovenian public enterprises. The Strategy of the further development of Slovenian public sector 2003-2005 (Government RS, 2003) mentions public enterprises only in one section 2.1. (Modernisation of legislation in the field of public services: public enterprises and public institutions), where it emphasises only the need to change the Law on public utilities from 1993, because it does not make a clear distinction between the government's role as an owner, manager and regulator of these entities. In the current Slovenia's Development Strategy 2006-2013 (Government RS, UMAR, 2005) public enterprises are mentioned only with regard to the governmental target to impose the evaluation of the biggest public sector organisations and companies in the majority ownership of the state with the EFOM methodology. Indirectly public enterprises are also linked with the following goals: to reduce the direct state role in the economy, to withdraw the state from the ownership of the companies and financial institutions and to diminish the role of KAD and SOD in the corporate governance and to introduce the public private partnerships (PPP) into the operation and financing of public services together with their infrastructure investments.

The Slovenian government has not realised its intentions to withdraw from the ownership of firms. Since the majority of utilities remain in the public ownership, it is particularly important to analyse the performance of the Slovenian public enterprises based on literature review and to find out what are the hidden reserves to increase the budget revenues, which could be especially welcome in the current economic crisis. This paper will also analyse if and how the investments of public enterprises and infrastructure investments have an impact on current budget deficit and public debt. For the definition of public enterprises we 
will follow the legislative provision in the Transparency of Financial Relations and Maintenance of Separate Accounts for Different Activities Act (ZPFOLERD, Official Journal RS, 53/2007, Official Journal RS, 65/2008). Public enterprises are defined as companies in which state and municipalities exercise direct or indirect majority influence through the majority share in the capital or assets of the founder. When determining the majority of the subscribed capital or assets the shares of various governmental bodies are being summed up. If the resulting sum of shares exceeds $50 \%$, the firm is considered to be a public enterprise.

The Act extends the notion of a public enterprise to those firms where bodies of the state and municipalities control the majority of voting rights deriving from their ownership and to those firms where they can nominate more than a half members of the board of directors or supervisory boards. Finding which enterprises are public based on the last two criteria is more troublesome, so we will relay on the first criterion based on the ownership share. We will focus in particular on the public enterprises that operate in infrastructure sectors (i.e. on public utilities).

\section{Effectiveness and efficiency of the Slovenian public enterprises}

In principle the effectiveness and efficiency of the firms has been measured with their profitability and other financial measures. If public enterprises operated in the competitive industries, their performance should be measured in the same way. However, the majority of the Slovenian public enterprises operate in the monopoly or natural monopoly industries. If these industries are regulated, the regulator imposes a cap on their profitability. Therefore, the profitability is not an adequate indicator of their performance. The indicators based on their expenditures, i.e. cost efficiency should be used instead. For this kind of analyse in local monopoly industries benchmarking studies of cost efficiency proved to be useful. They compare the firms' costs by taking into account various factors, which may affect the cost levels. This kind of analyses was conducted for Slovenian Gas and electricity distribution utilities and for Slovenian Water supply utilities. 


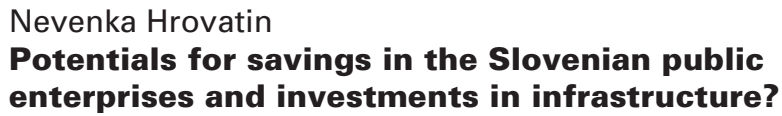

\subsection{Benchmarking analysis of the cost efficiency of Slovenian public utilities}

Data for the cost efficiency studies for water utilities were collected for 2004 with the assistance of the Ministry of the environment and spatial planning. 52 companies serving almost $80 \%$ of Slovenian municipalities submitted the data. Only 4 companies were private. Results are presented in more details in Fillipini, Hrovatin and Zorić (2010). Slovenian water supply companies achieved only $84 \%$ of the cost efficiency annually in the period 1997-2003. Of course, there were differences among firms, as the least cost efficient were only $67 \%$ efficient, while the most efficient $93 \%$. There were also significant differentials among the firms in the average cost per $\mathrm{m}^{3}$ of water supplied. The most expensive had seven times higher cost than the one with the lowest cost $\left(0.2\right.$ to 1.4 euro per $\mathrm{m}^{3}$ with the average of 0.54$)$. These differentials reflect different size of the firms as well as different business environment, such as the share of water supplied to the industry versus households, customer density, the share of water losses, the share of underground water and whether they need a heavy water treatment.

These findings show that potentials for the increase in efficiency of the Slovenian water utilities approach $15 \%$ on average, which could be transferred to the increase in their profitability without the need to raise prices. In this way the municipal budgets could get higher revenues. In seven years of the study coverage cost savings would amount to 74 million euro. Assuming the same cost levels and cost efficiency in the period $2004-2010$ the additional cost savings in these period would total 81 million euro. Moreover, the data indicated that water pipelines are quite obsolete since the water losses represented $27 \%$ of water supplied.

The increase in productivity of the Slovenian water supply utilities is also insufficient. The standard indicator of the productivity growth is total factor productivity (TFP). It is calculated as the ratio of output and input index. TFP is often used by regulators to determine the $X$ factor, which determines the required increase in productivity in the regulated companies in the next regulatory period. X normally varies among companies in the same industry due to differences in their achieved efficiency in the past. 
Results of the econometric analysis with stochastic cost frontier model ${ }^{\mathbf{1}}$ for the TFP growth of the Slovenian utilities for the supply of drinking water have demonstrated that TFP growth was $0.37 \%$ on average annually over the years 1997-2003. This could be compared to the results for the UK for slightly different period. In 1985 -1990 the TFP growth in the UK amounted to 2.3\% annually. It then slowed down to $1.6 \%$ in 1990-1999, but was still four times greater than in Slovenia.

Fillipini et al (2010) explain such differences with different regulatory setting. While Slovenian companies did not face the adequate regulatory constraints, that would have forced them to reduce costs, the British companies had to follow the RPI-X formula. This price-cap method of regulation stimulated companies to continuous cost reductions which was possible with productivity increases. On the contrary, in the Slovenian companies cost reductions did not contribute to the increase in TFP in the period under review. Productivity increases are attributable to technical change with $0.92 \%$ annual growth together with scale efficiency with $0.17 \%$ annual growth. On the other hand, change in output characteristics worked in the opposite direction causing $0.76 \%$ drop in TFP annually. In the whole period 1997-2003 the TFP increased by $2.2 \%$. Technical change contributed the majority of this growth with the $5.7 \%$ growth, which should be seen as a promising finding.

Public enterprises in Slovenia also exist in the distribution of natural gas. Huge potentials for cost savings have also been found in this sector. Zorić, Hrovatin and Scarsi (2009) conducted an international benchmarking study on Slovenian, British and Dutch gas distribution utilities using nonparametric DEA methodology. There were 14 Slovenian, 21 British and 7 Dutch firms in the sample for the year 2003. When the Slovenian utilities are compared with all firms in the sample (using DEA based on the constant returns to scale), their efficiency was only $33 \%$ (table 1). However, if we use more appropriate cost efficiency comparisons with DEA variable returns to scale, where Slovenian companies are compared only with the companies of the similar size in the sample, Slovenian utilities operated at $48 \%$ cost efficiency, Dutch with $77 \%$ and British with the greatest, $97 \%$ efficiency. This in fact means that Slovenian gas distribution utilities could distribute the same volume of gas with $52 \%$ lower costs. If we assume that the cost reduction would lead to the equivalent

1 The methodology for the econometric estimation of cost efficiency based on four models is presented in detail in Fillipini, Hrovatin and Zorić (2008). 
Nevenka Hrovatin

Potentials for savings in the Slovenian public

enterprises and investments in infrastructure?

increase in profit of their owners, private and public utilities, ${ }^{2}$ these could be used to finance also the infrastructure in related sectors, while the state would collect more corporate taxes. It is also worth mentioning that inefficiency partly stems from the small size of the utilities which does not allow them to exploit economies of scale. They reached only $80 \%$ of the efficiency from economies of scale (Zorić et al, 2009, p. 121).

Table 1: Average efficiency scores of the gas distribution utilities in the UK, Netherlands and Slovenia calculated by DEA methodology

\begin{tabular}{|l|c|c|c|c|}
\hline \multirow{2}{*}{ Model } & \multicolumn{4}{|c|}{ Efficiency scores } \\
\cline { 2 - 5 } & UK & Netherlands & Slovenia & Total \\
\hline \multirow{2}{*}{ DEA - CRS - average } & 0,777 & 0,731 & 0,326 & 0,604 \\
\hline \multirow{2}{*}{ DEA - VRS - average } & 0,969 & 0,770 & 0,480 & 0,707 \\
\hline
\end{tabular}

Note:

CRS - constant returns to scale

VRS - variable returns to scale

Source: Zorić et al (2009, p. 121).

2 There were 17 companies for the distribution of gas in Slovenia, 6 in the majority ownership of one or more municipalities and 9 with the majority private ownership. 
The authors explained greater inefficiency of Slovenian firms in comparison with foreign counterparts first with small size of the firms that prevents the exploitation of economies of scale and second with the inappropriate regulatory setting. In Slovenia the first regulatory period started only in 2006 in contrast to the UK, where the regulatory practice is much longer, starting with the privatisation of British Gas in 1986 and further developed with the separate regulation of gas distribution in 2002. Nevertheless, the results of the study should be in our view interpreted with caution. Lower cost efficiency of Slovenian firms may also be attributable to the wrong allocation of joint and common costs if the firms do business also in other sectors besides gas distribution. We assume that in the multiutility case the firms strived to allocate excessively high costs to the gas distribution if they could be covered from the end user prices. This could explain the empirical results of relatively higher costs of the Slovenian utilities.

Although Slovenian gas distribution companies are on average too small, some of them are too large in another related business, i.e. in the district heating, which also causes high costs. This was found by Bole and Jere (2006) for the gas distribution and district heating public enterprise Energetika Ljubljana, when they compared the firm with 178 Danish utilities in 2003. If Energetika is compared with the firms of similar size, it is found to be efficient. If it is compared only with the companies of the similar size, it is only $89 \%$ efficient. This implies that if Energetika operated as efficiently as the most efficient Danish companies, it would use $11 \%$ less primary energy and operating expenditures. Inefficiency of Energetika is driven by the fact that its district heating activity is too large and hence operates at the decreasing returns to scale. The excessive expansion of the firm in the district heating may not have been possible without public ownership, which may have supported less rational investment behaviour. Nevertheless, if the firm had the right size, it could have saved in nine years one annual costs for district heating.

Benchmarking cost efficiency analysis was repeated on behalf of the Energy Agency on the sample of Slovenian gas utilities only (Hrovatin and Zorić, 2009a). Several models were estimated on annual data for 2006-2008. The most robust models proved to be MOLS (Modified Ordinary Least Squares) and DEA models, which vary in terms of the included variables. All of 17 utilities operated with $69 \%$ of efficiency in the period. 7 of them were municipal public enterprises and 10 wholly or majority publicly owned. Private enterprises achieved higher, $72 \%$ of efficiency in contrast to public with only $66 \%$ 


\section{Nevenka Hrovatin \\ Potentials for savings in the Slovenian public \\ enterprises and investments in infrastructure?}

efficiency level. This implies that pubic enterprises in the Slovenian gas distribution could have obtained $34 \%$ of cost savings, which would consequently yield higher profits and also higher budget revenues.

Benchmarking cost efficiency analysis was also conducted for the Slovenian electricity distribution companies. In the first study of this kind for Slovenia, Fillipini, Hrovatin and Zorić (2004) showed that Slovenian electricity distribution companies are on average 35\% inefficient. The sample comprised of all 5 electricity distribution utilities in the period 1991-2000. The authors used loglog stochastic cost frontier function since the small data set prevented the use of a more appropriate translog model. They also found out that utilities are too small since they are operating on the increasing cost interval. Consequently they do not utilise cost savings associated with economies of scale. Mergers of utilities would be an appropriate policy recommendation, which was also suggested by Tajnikar et al (2002). This has been recently also envisaged by the Slovenian government although based on different grounds. ${ }^{3}$

Like for the gas distribution utilities, international benchmarking cost efficiency study of Slovenian firms with foreign counterparts was also done for the electricity distribution. DEA estimation methodology on OPEX (operating expenditures) data for 2003 (Netherlands 2000) was employed (Hrovatin, Zorić, Scarsi, Paripovič and Senčar, 2005). The sample consisted of 33 firms, 5 Slovenian, 11 British and 17 Dutch. Results of all DEA models assuming constant returns to scale have revealed the average $50.8 \%$ cost efficiency of all firms in the sample (table 2). British firms operated at the highest $58 \%$ cost efficiency level, followed with Dutch (50.1\%) and Slovenian with only 38\% cost efficiency. It is, however, more appropriate to compare each utility not with all in the sample, but only with those of the similar size. This is possible by estimating DEA models with variable returns to scale. Average efficiency level is now of course higher $-71.5 \%$. British companies are again the most efficient $(83.7 \%)$, followed by Dutch (67.7\%) with Slovenian firms $(57.7 \%)$ again in the last place. These findings have again indicated huge cost savings potentials of Slovenian firms. Lower cost efficiency of Slovenian firms versus the most efficient British counterparts could again be explained by the longer and successful regulatory tradition in the UK, which required from the utilities to reduce their operating costs.

3 The reorganisation of ownership and organisational structure of electricity distribution utilities have been anticipated driven by the findings of the Court of Audit of the Republic of Slovenia (CARS) about wrong organisational and contractual arrangements (CARS, 2009d, 2009e). For more on this see Hrovatin and Zorić (2010). 
Nevenka Hrovatin

Potentials for savings in the Slovenian public enterprises and investments in infrastructure?

Table 2: Efficiency scores of the electricity distribution utilities in Netherlands, the UK and Slovenia

\begin{tabular}{|l|c|c|c|c|}
\hline \multirow{2}{*}{ Model } & \multicolumn{4}{|c|}{ Efficiency scores } \\
\cline { 2 - 5 } & Netherlands & UK & Slovenia & Total \\
\hline \multirow{2}{*}{ DEA - CRS - average } & 0,501 & 0,579 & 0,376 & 0,508 \\
\hline DEA - VRS - average & 0,677 & 0,837 & 0,577 & 0,715 \\
\hline
\end{tabular}

Notes:

CRS - constant returns to scale

VRS - variable returns to scale

Source: Hrovatin et al (2005).

Like for the gas distribution utilities the benchmarking cost efficiency analysis was also repeated for electricity utilities on behalf of the Energy Agency on the more recent data set for 2004-2007 (Hrovatin and Zorić (2008)). The authors estimated several DEA and COLS models with variable OPEX (operating expenditures) as an input and various specifications outputs. ${ }^{4}$ The average cost efficiency of the firms in the whole period was $89 \%$, meaning that companies could every year distribute the same volume of electricity with $11 \%$ lower costs on average. This finding is of course better than in the first aforementioned benchmarking study for electricity distribution (Hrovatin et al, 2005), because the comparison is done only among Slovenian utilities without foreign counterparts. Significant variations among firms could also be seen. The most efficient firm operates at the $93 \%$ efficiency level, and the least efficient 11 percentage points less (i.e. 82\%). If the Slovenian electricity distribution utilities had operated efficiently in 2004-2007, they could have accumulated 35 million euro of cost savings, which would have been switched into equivalently higher profits. Taking into account the ownership structure, the

4 COLS (Corrected Ordinary Least Squares) is an econometric method, which is based on multivariate cost regression estimations using the OLS (Ordinary Least Squares) technique. Estimated cost function with OLS regression is than shifted downward, so that the most efficient firms lie on the shifted fitted curve. The difference between the fitted curve and actual observations represents the cost inefficiency of the firms. 
Nevenka Hrovatin

Potentials for savings in the Slovenian public

enterprises and investments in infrastructure?

state could have obtained $80 \%$ of the profit (with around $80 \%$ state ownership share), if the whole increase in profit would be allocated to dividends.

\subsection{Labour and other operating costs and profitability of the Slovenian public enterprises: evidence of some cases}

Opportunities for profitability improvements could be found also in other sources, such as in operating and labour costs. An average nominal gross wage in electricity and gas business (distribution and supply), where the Slovenian gas and electricity distribution public enterprises operate, increased from 2000 to 2007 more than the Slovenian average wage. The increase amounted to $81 \%$ compared of the Slovenian average of only $60.6 \%$ as the table 3 shows. While in 2000 the gross wage in this sector exceeded the Slovenian average by $14.4 \%$, in 2007 this gap widened to $29 \%$. It is not difficult to see that such faster increase in wages than Slovenian average resulted in the lower profits than in the more reasonable and modest wage expansions.

Table 3: Average nominal monthly gross wages in Slovenia and in the electricity and gas distribution and supply in 2000-2007 and their indexes

\begin{tabular}{|l|c|c|c|c|c|c|c|c|}
\hline $\begin{array}{l}\text { Nominal gross } \\
\text { wage/index }\end{array}$ & 2000 & 2001 & 2002 & 2003 & 2004 & 2005 & 2006 & 2007 \\
\hline $\begin{array}{l}\text { Monthly nominal gross wage (in } \\
\text { euro): Electricity and gas distri- } \\
\text { bution and supply (E) }\end{array}$ & 914.76 & $1,043.23$ & $1,155.94$ & $1,251.09$ & $1,353.46$ & $1,476.53$ & $1,559.60$ & $1,656.91$ \\
\hline $\begin{array}{l}\text { Monthly nominal gross wage (in } \\
\text { euro) : Slovenian average }\end{array}$ & 799.82 & 895.35 & 982.46 & $1,056.58$ & $1,116.55$ & $1,157.06$ & $1,212.80$ & $1,284.79$ \\
\hline Index E (previous year) & 114.0 & 110.8 & 108.2 & 108.2 & 109.1 & 105.6 & 106.2 \\
\hline $\begin{array}{l}\text { Index Slovenian average (previ- } \\
\text { ous year) }\end{array}$ & 114.4 & 116.5 & 117.7 & 118.4 & 121.2 & 127.6 & 128.6 & 129.0 \\
\hline $\begin{array}{l}\text { Index E/Slovenian average } \\
\text { Index E (base year 2000) }\end{array}$ & 100.0 & 114.0 & 126.4 & 136.8 & 148.0 & 161.4 & 170.5 & 181.1 \\
\hline $\begin{array}{l}\text { Index Slovenian average (base } \\
\text { year 2000) }\end{array}$ & 100.0 & 111.9 & 122.8 & 132.1 & 139.6 & 144.7 & 151.6 & 160.6 \\
\hline
\end{tabular}

Source: Statistical Yearbook of the Republic of Slovenia 2008 (SORS, 2009). 
Potentials for savings in the Slovenian public enterprises and investments in infrastructure?

Real gross wages have, of course, increased less (table 4), although they still demonstrate large discrepancies between the industry and the Slovenian average. While the average Slovenian gross increased in real terms by $16 \%$, the gas and electricity distribution and supply industry faced an increase of almost twice as much, i.e. $31 \%$.

Table 4: Average real monthly gross wages in Slovenia and in the electricity and gas distribution and supply in 2000-2007 and their indexes (base year 2007)

\begin{tabular}{|c|c|c|c|c|c|c|c|c|}
\hline Industry/index & 2000 & 2001 & 2002 & 2003 & 2004 & 2005 & 2006 & 2007 \\
\hline $\begin{array}{l}\text { Monthly real gross wage (in euro): } \\
\text { Electricity and gas distribution and } \\
\text { supply (E) }\end{array}$ & 1,269 & 1,335 & 1,376 & 1,411 & 1,473 & 1,568 & 1,616 & 1,657 \\
\hline $\begin{array}{l}\text { Monthly real gross wage (in euro): } \\
\text { Slovenian average }\end{array}$ & 1,110 & 1,146 & 1,170 & 1,191 & 1,215 & 1,229 & 1,256 & 1,285 \\
\hline Chain index $\mathrm{E}$ & & 105 & 103 & 102 & 104 & 106 & 103 & 103 \\
\hline Chain index Slovenian average & & 103 & 102 & 102 & 102 & 101 & 102 & 102 \\
\hline Index E (base year (2000) & 100 & 105 & 108 & 111 & 116 & 124 & 127 & 131 \\
\hline $\begin{array}{l}\text { Index Slovenian average } \\
\text { (base year 2000) }\end{array}$ & 100 & 103 & 105 & 107 & 110 & 111 & 113 & 116 \\
\hline
\end{tabular}

Source: Statistical Yearbook of the Republic of Slovenia 2008 (SORS, 2009).

It is also worth mentioning that labour costs in electricity distribution utilities exceed the allowed level set by the regulator. This happens since utilities pay higher holiday compensations than in other public sector institutions and in other industries. In addition employees get the thirteenth wage, Christmas earnings and other benefits and rewards, which the Energy Agency of the Republic of Slovenia (EARS) does not consider being a part of required revenue and could not be calculated in the price. As a consequence utilities and their owners (i.e. the state as a majority owner) receive lower profits. A similar practice has been noticed in other public firms in the electricity industry. 
Nevenka Hrovatin

Potentials for savings in the Slovenian public

enterprises and investments in infrastructure?

Table 5: Performance indicators for the distribution activity and for the firm as whole for Slovenian electricity distribution utilities in 2007

\begin{tabular}{|c|c|c|c|c|c|c|c|c|c|c|}
\hline \multirow{2}{*}{$\begin{array}{l}\text { Company } \\
\text { Activity }\end{array}$} & \multicolumn{2}{|c|}{$\begin{array}{l}\text { Elektro } \\
\text { Maribor }\end{array}$} & \multicolumn{2}{|c|}{$\begin{array}{c}\text { Elektro } \\
\text { Celje }\end{array}$} & \multicolumn{2}{|c|}{$\begin{array}{c}\text { Elektro } \\
\text { Gorenjska }\end{array}$} & \multicolumn{2}{|c|}{$\begin{array}{c}\text { Eektro } \\
\text { Ljubljana }\end{array}$} & \multicolumn{2}{|c|}{$\begin{array}{c}\text { Elektro } \\
\text { Primorska }\end{array}$} \\
\hline & SODO & Total & SODO & Total & SODO & Total & SODO & Total & SODO & Total \\
\hline $\begin{array}{l}\text { Ratio total } \\
\text { revnues/ } \\
\text { expenditures }\end{array}$ & 0.980 & 1.011 & 0.970 & 1.002 & 1.064 & 1.019 & 1.020 & 1.004 & 0.994 & 1.009 \\
\hline $\begin{array}{l}\text { Ratio total reve- } \\
\text { nues from business } \\
\text { actities/ } \\
\text { expenditures }\end{array}$ & 0.963 & 1.003 & 0.952 & 0.990 & 1.068 & 1.021 & 1.013 & 1.003 & 0.993 & 1.011 \\
\hline ROA & $-0.35 \%$ & $0.88 \%$ & $-0.78 \%$ & $0.31 \%$ & $1.51 \%$ & $1.31 \%$ & $0.87 \%$ & $0.89 \%$ & $-0.16 \%$ & $1.20 \%$ \\
\hline ROE & $-0.53 \%$ & $0.86 \%$ & $-0.90 \%$ & $0.21 \%$ & $1.29 \%$ & $1.00 \%$ & $0.63 \%$ & $0.38 \%$ & $-0.20 \%$ & $0.89 \%$ \\
\hline
\end{tabular}

Legend:

SODO - activities carried out by the distribution system operator

Total - performance of the company whole taking into account all of its activities.

$R O A$ - return on assets

$R O E$ - return on equity

Source: Elektro Gorenjska (2008), Elektro Ljubljana (2008), Elektro Primorska (2008), Elektro Maribor (2008) and Elektro Celje (2008).

As the table 5 shows, it is not surprising that excessive labour costs together with other high operating and capital costs lead to low profitability of the utilities. The Energy Agency allowed the companies to receive $4.13 \%$ return on assets in the regulatory period 2006-2008 (EARS, 2005). Instead of approaching the allowed rate of return, three out five utilities operated at loss in 2007 in the distribution of electricity as shown in the table 5 and the two remaining earned significantly lower returns $(1.51 \%$ and $0.87 \%)$. The performance of utilities overall (accounting for all activities) was also disappointing with the profitability (return on assets - ROA) between $0.31 \%$ and $1.51 \%$. This clearly demonstrates underperformance and inadequate use of public assets. Low profitability or losses driven by stiff competition has been lately recorded also in the electricity supply (trade) (Šepic, 2010). The key issue to be answered is whether the competition among firms with the same majority owner that results in lower profitability of all, makes sense. An alternative model 
would be to withdraw the supply business from the firms with the transfer of assets to a new founded firm for the supply of electricity. In this way wasteful competition among firms with the same owner would be abandoned.

Inefficient corporate governance of public assets was found out and criticised also by CARS. On the basis of public audit for the period 2005-2007 CARS warned the public enterprise for the construction and renewal of highways DARS for its inefficient and ineffective maintenance of highways (CARS, 2010). ${ }^{\mathbf{5}}$ The main findings are:

1. DARS does not have a strategy for the highways maintenance that would be harmonised with the Resolution on the national programme for the construction of highways in Slovenia.

2. It receives compensation for conducting public procurements which is based on the value of works done. It does not have an incentive to select the lowest bidder, since it receives greater compensation from the greater value of works. Also if the value of works done is lower, it receives a variable reward for this achievement.

3. It has not done any long-run analysis and maintenance plans which would enable to compare what is more cost effective: higher cost of regular maintenance in conjunction with lower investment maintenance costs afterwards or the other way around.

4. DARS does not have any international comparisons of maintenance costs associated with the use of alternative construction materials in the construction of highways.

5. Maintenance costs per $\mathrm{km}$ of highways have been increasing more rapidly than the length of the constructed highways in total.

6. DARS has managed to accomplish only between $19 \%$ to $31 \%$ of regular maintenance work (filling the gaps), which may lately bring about higher costs of investment maintenance.

7. DARS has outsourced the preparation of professional and technical background for conducting public procurement procedures to the company DDC, consulting and engineering, on the contractual basis. The conflict of interest could clearly be seen as DDC is paid according to the value of the planned investment works rather than to its actual work done based on the working hours. To maximise its earnings it is interested to plan high amount of investments works and their values.

\footnotetext{
${ }^{5}$ The CARS has also pointed out the inappropriateness of the concession contract and other shortcomings and faults in the construction of highways. For more information on this see Hrovatin (2010).
} 


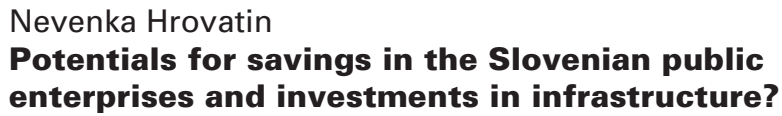

In conclusion, the entire system of regular and investment maintenance of highways in DARS is organised in such way that it enhances higher use of public resources and lower efficiency on behalf of the higher profitability of public enterprises DARS and DCC. The inefficiencies were not revealed only in the maintenance of highways but according to the audit reports of CARS also in the maintenance of municipalities' roads in some Slovenian municipalities.

The CARS has also highlighted the inefficient use of budget sources in the obligatory local public service of managing the public green areas and parks (CARS, 2009c). In 2007 municipalities have not established a procedure enabling efficient use of public funds. Municipalities define only the value of needed resources without prescribing how the resources should be used and what the required quality is. Due to the lack of prescribed targets, the use of funds was left to the firms managing the green areas without any control on how efficiently and effectively the funds were spent.

\section{Public support for the renewable energy sources}

Public support schemes for the development of renewable energy sources and combined heat and power with high exploitation also represent potentials for savings in both, public and private firms. Slovenian government supports the generation of electricity with feed-in-tariffs in conjunction with the compulsory purchase of electricity in small power plants of up to $5 \mathrm{MW}$ and with financial contributions to cover operating expenses for other units. (Energy Act-C, 2008). Support systems should be in place as the electricity from renewables and co-generation of heat and power with high exploitation is more costly than electricity from conventional sources. Without supporting schemes these power plants could not compete in the market. Government thus provides supports to the firms to fill in the gap between higher generation costs and lower market prices. Funds for the feed-in-tariffs have been collected by a special centre for supports within the power exchange Borzen. They are incorporated into the use of network charges as a compulsory contribution of all electricity consumers. It is estimated that every year around 45 million euro of support funds will be collected (Hrovatin and Zorić, 2009b; Zorić 
and Hrovatin, 2010). The majority of 599 recipients of feed-in-tariffs and contributions in 2008 were small hydropower plants and solar power plants.

Compulsory collection of funds could be partly replaced by direct payments of electricity consumers for green energy. This would in turn make possible to use compulsory payments incorporated in the use of network charges as additional excise duties on electricity for reducing the budget deficit. ${ }^{6}$ How many compulsory collected funds could be replaced with the consumers' voluntary contributions of course depends on the willingness to pay of Slovenian households for green electricity. Of course, it would be more desirable not to use the compulsory contributions from use of network charges to increase excise duties, but to use both compulsory and voluntary collected payments for stimulating the investments into the use of renewable energy sources. In fact, investments into these and related business would in the long-run from the supply side increase the budget revenues (through profits and taxes). Therefore, shifting the compulsory contributions into excise duties on electricity could be only used temporarily in times of crisis to help the state budget to recover.

The study on the willingness to pay for green electricity conducted by Zorić and Hrovatin (2010) for 2008 using the sample of 450 Slovenian households has revealed that $77 \%$ of the households are willing to pay on average 4.2 euro monthly, which represents $10.5 \%$ of the monthly electricity bill. If only those households that are willing to pay are taken into account, the monthly payment is even higher (5.4 euro monthly). 745.000 households (data for 2007) would be willing to pay 37.5 million together for green electricity. Actual payments would most likely be lower, as the stated preferences may exaggerate the real willingness to pay. On the other hand, higher payments could be realised with the right marketing and policy actions targeted to the households with higher education, incomes and environmental awareness. The econometric estimations have proven that these households are more willing to pay for green electricity. Creating appropriate marketing strategies in the firms and better information campaigns in the relevant state authorities would trigger the achievement of these goals.

6 Excise duties are a controversial issue. On the one hand they raise budget revenues, while on the other they hinder the competitiveness of the firm. Discussion on this issue would go beyond the aim of this paper. 
Nevenka Hrovatin

Potentials for savings in the Slovenian public

enterprises and investments in infrastructure?

\section{Public-private partnerships in infrastructure investments as a mean to reduce public financing}

Raising credits by public enterprises for infrastructure investments does not increase the official public debt and does not impose a burden on the current budget. It is just the opposite when the state or municipalities raise credits by themselves to finance investments in infrastructure. The state guarantees are also not included in the public debt. However, they represent a potential threat for public financing, as they are transferred into the public debt when the creditor claims guarantees for debt repayment. Although public enterprises in their credit activities normally do not cause the increase in public debt, the recent tendencies of increasing public ownership in Slovenia and the absence to exploit opportunities offered by public-private partnerships in infrastructure financing should be in our view of great concern.

Before the crisis Slovenia did not use the opportunity to attract private financing into infrastructure projects through various forms of public-private partnerships (PPP). ${ }^{7}$ Slovenia participates with only $0.1 \%$ in all European PPPs, whose value is almost negligible (EIB, 2007). Together with Denmark, Latvia, an Slovak republic it is placed last regarding the development of PPPs. PPPs are the most represented in the UK with the $56 \%$ share by value, followed by Spain, France, Germany and Italy with a total share of one third of PPPs by value (EIB, 2007).

In the ownership structure of public enterprises the Slovenian state went backward when passing the PPP Act (2006). This Act provides an incentive to public enterprises (with mixed ownership), who run their activities by concessions, to withdraw the private shares from the companies. If they do so and

7 The rationale for underrepresentation of PPPs in Slovenia have been analysed in more detail by Hrovatin (2010). The key reasons are:

- late adoption of legislation and delays in its implementation in practice,

- reliance on the public financing of the highways and railways construction which was possible because of low indebtedness of the state and thus compliance to the Maastricht's fiscal criteria without problems,

- $\quad$ the pattern of ownership transformation of companies in transition leading to the majority of public utilities being organised as public enterprises,

- $\quad$ the recent reorganisation of public enterprises as required by the Public Private Partnerships Act (2006), enhancing the ownership share of the state and municipalities,

- failures that happened in conducting the first PPPs in Slovenia (the case of water treatment in Maribor). 
end up as a $100 \%$ publicly owned, they could continue with their businesses without getting the concession through public procurement procedure. On the contrary, if they keep private ownership shares, they have to compete for the concession in public procurement with other rivals. In addition, an increased influence of the municipalities was enacted in 2010 with the provision that infrastructure belongs to the municipalities. Municipalities could lease the infrastructure to public enterprises. The rent should cover at least depreciation of the assets. If the rent is agreed on such a minimum level, it is clear that the financial resources do not suffice for new investments. In the previous regime the infrastructure could be recorded in the sub-balance sheets of the public enterprises as the "assets in management", meaning that municipalities were indirect owners of the assets. Public enterprises had more business freedom to efficiently manage the infrastructure than in the new regime.

With these increase of "public" Slovenia has also launched more opportunities to increase public financing and hence public debt. Although the indebtednesses of municipalities in 2007 represented only $2.6 \%$ of public debt (CARS, 2009a), the debt of municipalities tends to increase. Only in two years, from 2007 to 2009, the gross indebtedness of the municipalities increased almost five times, and their net indebtedness 6.6 times as table 6 shows.

Table 6: Borrowing of Slovenian municipalities in 2007 - 2009 in euro

\begin{tabular}{|l|c|c|c|c|}
\hline & 2007 & 2008 & 2009 & $\begin{array}{c}\text { index } \\
2009 / 2007\end{array}$ \\
\hline Borrowing & 41.603 .813 & 126.322 .007 & 198.991 .158 & 478,3 \\
\hline Amortization of debt & 17.435 .737 & 23.377 .435 & 38.202 .260 & 219,1 \\
\hline Net borrowing & 24.168 .076 & 102.944 .572 & 160.788 .898 & 665,3 \\
\hline
\end{tabular}

Source: MF (2010b).

The accumulated budget deficit of municipalities in 2007 was negligible $(-0.1$ GDP), but in 2008 it considerably increased to $0.6 \%$ of GDP and remained around this level (0.5\% of GDP) also in 2009 (MF and SORS, 2010). 


\section{Nevenka Hrovatin \\ Potentials for savings in the Slovenian public \\ enterprises and investments in infrastructure?}

The majority of municipalities' loans are raised for the construction of schools, kindergartens, and sport halls, followed by loans for the construction of communal infrastructure (water pipelines and sewerage, waste water treatment plants). Municipalities face constraints in their credit financing. They can only borrow if the debt servicing and obligations imposed by given guarantees do not exceed $8 \%$ of municipalities' revenues in the previous year from which donations and transfer payments for investments from the state budget, payments from the EU budget and revenues of the municipal public utility plants (in Slovene »režijski obrat») are deducted. Public private partnerships which would remove a burden of infrastructure financing from municipal budgets would be in particular welcome at the municipal level. Unfortunately, this instrument is underdeveloped in Slovenian municipalities as the evidence witnessed. 77 of the Slovenian municipalities or more than one third (36.4\%) has not signed any PPP contract. This is 8 more than in 2008. Only one contract was concluded in 49 municipalities. Average number of contracts per municipality is 1.95 or, if we take into account only those municipalities, which have signed contracts, 3.09. The largest number of singed contract in a municipality is 14 (Financing of municipalities and accountable governance of municipalities' property, 2010).

The current economic and financial crisis has severely challenged also PPP type of infrastructure financing, which forced municipalities to find alternative revenues. In the UK, for example, municipalities are trying to find additional budget revenues in local betterment taxes. Planning gain is paid by developers of new dwellings who received higher profits (gains) as a result of the change of the purpose of the land use. Another possibility is also collection of compulsory contribution from the constructor (planning obligation) for the construction of communal infrastructure in new developments and associated social infrastructure (new schools, kindergartens, health centres, etc.) (Bailey, 2010).

On the state level state loans and state guarantees for the infrastructure construction seem to be more tricky because of its larger size. Although in Europe the most PPPs have been in the transport sector $(60 \%$ by number and $84 \%$ by value) with highways in the first place, Slovenia did not succeed to take advantage of private sector participation in the construction of highways. The entire Slovenian highway cross has been constructed with public funds by the public enterprise DARS. The state has been granting guarantees to DARS for its loans. It is not surprising that these guarantees represented the largest 
Potentials for savings in the Slovenian public enterprises and investments in infrastructure?

share in all state guarantees in the period 2000 - 2009 (MF, 2010a). State guarantees have escalated from 1.206 million euro in 2001 to 4.957 million euro in 2009 or from $5.8 \%$ of GDP in 2001 to $12.7 \%$ of GDP in 2008 and finally to $20,5 \%$ of GDP in $2010 .^{\mathbf{s}}$

CARS has pointed out several deficiencies in highway construction: delays in construction, nonfulfilment of planed construction works by the deadline, exceeding planned investment resources, inappropriate concession arrangements and allocation of responsibilities among the state, DARS and the firms for the state roads. Further threats in the financing of the highway construction programme are envisaged in the need for raising additional loans and in the problems in servicing already raised loans. The anticipations of CARS, that financing of highway construction may last longer than planned (by 2033) so that its completion may be postponed to 2050 come as no surprise (CARS, 2009b and Hrovatin, 2010).

Unlike the construction of highways, the state has not seriously questioned the need for the modernisation of Slovenian railways. Until 2007 only one fourth of the planned modernisation programme that should be completed by that time had in fact been realised. The state had also been giving guarantees to railways in the past and took over some loans which increased the state capital in the firm. Also, some financial assistance was given for solving redundancies and human resource restructuring. If this practice continues in the future, the budget expenditures would increase which would in turn raise state borrowing. The governmental will to prepare the revitalisation and modernisation of railways having private participation in mind seems promising to hinder the past practice.

The current size of state guarantees will also expand due to the envisaged guarantees for the construction of new lignite-fired thermal power plant in Šoštanj (TEŠ 6). If the public financing may to some extent may be justified in highway construction, it is much more difficult to accept this way of financing in the energy sector. The electricity industry has faced tremendous transformation under the EU liberalisation legislation and practice. In particular in the generation private initiative should lead the investment decisions and their financing. Some countries, like Finland, even went so far that the construction of two new nuclear power plant has not been entrusted to a public enterprise, but to two private non-profit consortia instead (Gatermann, 2010).

8 Considerable raise of guarantees in 2010 is mostly attributable to the guarantees of the state to help solving the financial crisis and was caused by infrastructure investments. 


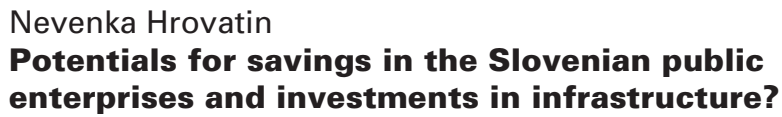

\section{Management of public enterprises}

Efficient management of public enterprises is a prerequisite for significant cost savings and thus their better performance. The theoretical model of Schleifer and Vishny (1994) has demonstrated that public enterprises employ too many workers and gets reward transfers from the budget if the state exercises political influence through the majority ownership in the firms. Managers in public enterprises subordinate to the will of the politicians in order to keep their managerial positions. Hence, they will fulfil politicians' requirements to reward the loyalty of political parties' colleagues with hiring them for posts in public enterprises. Redek (2008) upgraded the basic Scheifer - Vishny's model with the assumption, that politicians are constrained in their attempts of providing jobs with the fear of scandal due to the media revelations about their wrong practices. In addition, inexperienced staff raises costs of the public enterprises due to the lack of knowledge and skills. In this way, media in their information role about the politicians' behaviour, act as a control mechanism against the tendency of overstaffing in public enterprises and against inadequate labour qualifications.

To prevent a negative influence of politicians on the appointment of unqualified managers based on their political affiliation, an efficient selection mechanism should be established. Slovenia attempted to launch such a mechanism for the appointment of the supervisory board members with the foundation of human resource accreditation committee. Since this was done only for supervisory boards, the main criterion for the top managerial posts remains to be political affiliation and loyalty together with good connections with political elite.

Efficient managerial leadership and performance could also be stimulated with adequate remuneration system. The fundamental rule should be that managers in public enterprises receive equal payments as managers in the private companies with similar risk. Such remuneration schemes are recommended also by the United Nations (2005). If public enterprises enjoy monopoly status and bear lower risks, their managers should earn lower wages and other payments. It is also recommended that managers' payments should consist of a fixed and a variable part. The variable part should be tied to the achievement of predefined targets. If public enterprises do business in noncompetitive markets, the predefined target could not be the earned profit alone, but other goals such as cost reductions, higher quality of products and 
services, success in reorganisation of business processes and in restructuring and the like. The focus, thus, should be on the specification of predetermined results (targets) and on the measurement of their implementation, which as a consequence determines managers' level of remuneration. Performance contracts between the state as the principal and the public enterprise as an agent have been successfully implemented in OECD countries and in some developing countries (India, Korea) (United Nations, 2005 and Chaterjee, 2010). In these contracts the targets (expected results) are defined in detail. This system also allows calculating the efficiency and/or effectiveness of public enterprises' performance which further enables their ranking and hence serves as a foundation for determining the top managers' remunerations.

From this perspective the Slovenian managerial remuneration system, where the managers' remuneration is tied to the average wage in each public enterprise, seems to be wrong. It gives managers in the industries with higher average wages higher remunerations no matter if the companies perform worse and do not reach the results. Slovenia, thus, needs both: first performance contracts between the state and public enterprises about the specified targets and second, top management remunerations tied to the achievement of these targets.

\section{Conclusions}

Analysis of potential savings of the Slovenian public enterprises has revealed significant abilities for cost reductions and consequently for the increase in their profitability. This would raise revenues of their owners - the state and municipalities directly as a share in increased profit and by collecting higher corporate taxes. Benchmarking analysis of the gas and electricity distribution firms as well as water supply utilities have indicated potentials of $34 \%$, $11 \%$ and $16 \%$ average annual cost reductions annually, if Slovenian firms are compared only among themselves. In the comparisons with foreign firms, even larger savings could be achieved. A part of their inefficiency is associated with the fact that they are too small. With the mergers of firms without any additional efforts some cost savings could be accomplished.

As the studies took into account only operating costs, real costs savings would be even greater if the costs of capital are also incorporated. Among operating costs labour costs also proved to be too high. The CARS has also 


\section{Nevenka Hrovatin \\ Potentials for savings in the Slovenian public enterprises and investments in infrastructure?}

pointed out several inefficiencies in the construction and maintenance of highways and roads and in the management of green public areas.

Additional budget sources could also indirectly be collected from users of public services by using their willingness to pay for certain products and services (i.e. green electricity). Further reduction in public spending is also possible with the greater use of PPPs for infrastructure financing. Slovenia has achieved very limited results in this area. Nevertheless, potential savings could not be realised without the efficient management of public enterprises. To pursue this key target Slovenia should introduce at least two reforms. First, the performance contracts between the state and public enterprises about the targets should be established and second, the appropriate recruitment and remuneration schemes for public sector managers should be designed, where the managerial remuneration would be tied to the accomplishment of predefined targets.

Nevenka Hrovatin is Professor of Economics at the Faculty of Economics, University of Ljubljana, Slovenia (FELU). Her research interest is oriented towards public sector and public utilities with special focus on energy, water and electronic communications. She has been teaching several courses in these fields. From October 2001 to October 2007 she had been acting as Vice-Dean for International Relations. She is the head of the Institute of Public Sector at the FELU, the head of the master's programme in business administration that the FELU organises together with the ICPE and the head of Joint Master's Programme in Public Sector and Environmental Economics that the FELU is running together with the Schools of Economics and Business, University of Sarajevo and University of Nice (Tempus project). She is a member of the Energy Council of the Government of Slovenia and the Public-Private Partnership Council at the Ministry of Finance. She is a member of the editorial board of the journal Uprava (Administration). From 1999 to June 2010 she was co-editor of the Economic and Business Review for Central and South-Eastern Europe. She has also been working as a consultant to the Slovenian Government, the Slovenian electricity and gas regulator the Energy Agency and several utilities. In the past she was member (president) of supervisory boards of several Slovenian companies and institutions. 


\section{Nevenka Hrovatin \\ Potentials for savings in the Slovenian public enterprises and investments in infrastructure?}

\section{References}

- Bailey, S.J. (2010): Alternative models for funding public sector infrastructure: UK policy and practice. Slides for the lecture at the Faculty of Economics, University of Ljubljana, 26 May 2010.

- Bole, V., Jere, Ž. (2006): Stroškovna, tehnična in ekološka učinkovitost Energetike Ljubljana. (Cost, technical and ecological efficiency of Energetika Ljubljana). Gospodarska gibanja, št. 382, junij 2006, pp. 31-46.

- CARS (Court of Audit of the Republic of Slovenia) (2009a) Revizijsko poročilo: Zadolževanje občin (Audit Report. Borrowing of municipalities).

- $\quad$ CARS (2009b) Revizijsko poročilo. Izvajanje in financiranje programa gradnje avtocest (Audit Report. Implementing and financing of the programme for the construction of highways).

- $\quad$ CARS (2009c): Revizijsko poročilo. Urejanje javnih zelenih površin (Audit Report. Maintenance of green public areas).

- CARS (2009d): Revizijsko poročilo. Ureditev izvajanja gospodarske javne službe sistemskega operaterja distribucijskega omrežja (Audit Report. Arrangement for implementing the public service of the distribution system operator).

- $\quad$ CARS (2009e): Porevizijsko poročilo. Popravljalni ukrepi Ministrstva za gospodarstvo in družbe SODO, d.o.o., sistemski operater distribucijskega omrežja električne energije, Maribor (After Audit Report. Correcting measures of the Ministry for the Economy and the company SODO, the electricity distribution system operator).

- $\quad$ CARS (2010): Revizijsko poročilo. Vzdrževanje avtocest (Audit Report. Maintenance of highways).

- Chatterjee, B. (2010): World Class Managemenet of Public Enterprises in India. Slides for the lecture of the IAS Secretary in the Department of Public Enterprises, Government of India held at the International Center for Promotion of Enterprises, ICPE, 16 June 2010.

- $\quad$ EARS (Agencija za energijo republike Slovenije, Energy Agency of the Republic of Slovenia (2005): Akt o določitvi metodologije za obračunavanje omrežnine in metodologije za določitev omrežnine in kriterijih za ugotavljanje upravičenih stroškov za elektroenergetska omrežja. (Rules on determining the methodology for the calculation of use of network charges and methodology on the determination of the use of network charges and criteria to determine justifed costs of electricity networks). Official Journal RS, $121 / 2005$.

- $\quad$ EC (European Commision), Eurostat: ESA 95 manual on government deficit and debt. Luxembourg: Office for Official Publications of the European Communities.

- $\quad$ Elektro Celje (2008): Letno poročilo za leto 2007 (Annual Report for 2007).

- Elektro Gorenjska (2008): Letno poročilo 2007 (Annual Report 2007).

- Elektro Ljubljana (2008): Letno poročilo Elektra Ljubljana d.d. za leto 2007 (Annual Report of Elektro Ljubljana d.d. for 2007). 


\section{Nevenka Hrovatin \\ Potentials for savings in the Slovenian public enterprises and investments in infrastructure?}

- Elektro Maribor (2008): Letno poročilo 2007 (Annual Report 2007).

- Elektro Primorska (2008): Letno poročilo družbe za leto 2007 (Annual Report of the company for 2007).

- $\quad$ European Investment Bank (EIB) (2007): Public - Private Partnerships in Europe. Economic and Financial Report 2007/3 (By Bland-Brude F., Goldsmith, H. and Välilä, T.).

- $\quad$ EZ-C (2008): (Zakon o spremembah in dopolnitvah Energetskega zakona) (Act Amending the Energy Act). Official Journal RS, 70/2008.

- Fillipini, M., Hrovatin, N., Zorič, J. (2004) Effeciency and regulation of the Slovenian electricity distribution companies. Energy policy, vol. 32, no. , pp. 335-344.

- Fillipini, M., Hrovatin, N., Zorič, J. (2008) Cost efficiency of Slovenian water distribution utilities : an application of stochastic frontier methods. Journal of productivity analysis, 2008, no. 2, vol. 29, pp. 169-182.

- $\quad$ Fillipini, M., Hrovatin, N., Zorič, J. (2010) Productivity growth and price regulation of Slovenian water distribution utilities. Zbornik radova Ekonomskog fakulteta u Rijeci 28(1), pp. 89-112.

- Financing of municipalities and accountable governance of municipalities' property (2010) ( In Slovene: Financiranje občin in odgovorno upravljanje občinskega premoženja). Tu\&Zdaj. Informator Socialnih demokratov (Informator of Social democrats), no. 16, April 2010.

- Gatermann R. (2010) The Finnish way: nonprofit nuclear power. European Energy Review, 22 May 2010. Accessed on 25 May from

http://www.europeanenergyreview.eu/index.php?id_mailing=73\&toegang=d2ddea18f00 665 ce8623e36bd4e3c7c5\&id $=1967$

- Government of the Republic of Slovenia (Government RS) (2003) Strategija nadaljnjega razvoja slovenskega javnega sektorja 2003-2005. (The Strategy of the further development of Slovenian public sector 2003-2005).

- Government RS, UMAR (2005): Strategija razvoja Slovenije (Slovenia's Development Strategy).

- Hrovatin, N. (2010): Public Private Partnerships in Slovenia: Reverse Financial Innovations Enhancing the Public Role. In Bailey, S.J., Pekka, V., Anttiroiko, A.-V. (editors) Innovations in Financing Public Services. Country Case Studies. Palgrave Macmillan (in print).

- Hrovatin, N., Zorić, J. (2008): Benčmarking analiza učinkovitosti dejavnosti distribucije električne energije in predlog za uporabo rezultatov analize pri regulaciji cen za uporabo distribucijskega omrežja. Študija. (Benchmarking analysis of the efficiency of distribution of electricity and suggestions to use the results in the price regulation of the distribution network charges. Study). Študija. Ljubljana: Inštitut za javni sektor, RCEF, Ekonomska fakulteta Univerze v Ljubljani. Naročnik: Javna Agencija RS za energijo. (On behalf of the Energy Agency of the Republic of Slovenia). 


\section{Nevenka Hrovatin \\ Potentials for savings in the Slovenian public enterprises and investments in infrastructure?}

- Hrovatin, N., Zorić, J. (2009a): Primerjalna analiza učinkovitosti dejavnosti sistemskih operaterjev distribucijskih omrežij zemeljskega plina. Študija. (Benchmarking efficiency analysis of distribution system operators, study). Ljubljana: Inštitut za javni sektor, RCEF, Ekonomska fakulteta Univerze v Ljubljani. Naročnik: Javna Agencija RS za energijo.

- Hrovatin, N., Zorić, J. (2009b): Ali so slovenski uporabniki pripravljeni plačati za zeleno energijo?. (Are Slovenian customers willing to pay for green electricity?) In Kovačič, V., Černelč Koprivnikar, M. (editors). Inovacija energetike?. Ljubljana: Prosperia, 2009, pp. 23.

- Hrovatin, N., Zorič, J. (2010): Reforme elektroenergetskega sektorja v EU in Sloveniji. (Reforms of the electricity sector in the EU and Slovenia). Ljubljana: Ekonomska fakulteta Univerze v Ljubljani (forthcoming). Ljubljana: Ekonomska fakulteta

- Hrovatin, N., Zorić, J., Scarsi, G. C., Paripovič, M, Senčar, M. (2005): The relative performance of electricity distribution utilities from Slovenia, the Netherlands and the UK: an application of data envelopment analysis. Economic and business review, December 2005, vol. 7, no. 4, pp. 329-349.

- Ministry of finance (MF) (2010a): Poroštva in jamstva republike Slovenije. Poročilo za leto 2009. (Guarantees of the republic of Slovenia. Report for the year 2009).

- Ministry of finance (MF) (2010b): Bilance proračunov občin (Municipalities' budgets). Accessed on 10 July 2010 from http://www.mf.gov.si/slov/fin_loksk/bilance.htm

- Ministry of finance (MF), Statistical Office of the Republic of Slovenia (SORS) (2010) Poročilo o primanjkljaju in dolgu države - april 2010 (pripravljeno na osnovi metodologije ESA 95) (Report on the deficit and debt of the state - April 2010 (prepared according to the ESA 95 methodology).

- Public-Private Partnership Act (PPP Act) (2006): (In Slovene: Zakon o javno-zasebnem partnerstvu - ZJZP). Official Journal RS, 127/2006.

- Redek, T. (2008): Dolga roka države: politika in uspešnost podjetij (Politicians: A Threat to Firms?). Naše gospodarstvo, št. 5-6, letnik 54, str. 32-42.

- Schleifer, A., Vishny R.W. (1994): Politicians and Firms. The Quarterly Journal of Economics, no. 4, vol. 109, pp. 995-1025.

- SORS (Statistical Office of the Republic of Slovenia (2009): Statistical Yearbook of the Republic of Slovenia 2008.

- Štepic, Z. (2010). Analiza konkurence podjetja Elektro Ljubljana na področju prodaje električne energije. Specialistično delo (Analysis of the competition of Elektro Ljubljana in the supply of electricity. Specialist thesis.). Ljubljana: Ekonomska fakulteta.

- Tajnikar, M., Hrovatin, N., Lahovnik, M., Ponikvar, N., Rant, M., Došenović Bonča, P., Zorić, J. (2002): Projekt koncentracije kapitala in poslovnih funkcij v elektrodistribucijskem sistemu Republike Slovenije (Project of concentration of capital and business functions in the electricity distribution system of the Republic of Slovenia). Ljubljana: Ekonomska fakulteta. 


\section{Nevenka Hrovatin \\ Potentials for savings in the Slovenian public \\ enterprises and investments in infrastructure?}

- United Nations (2005): Public Enterprises: Unresolved Challenges and New Opportunities. Publication based on the Expert Group Meeting on Re-inventing Public Enterprise and their Management, 27 - 28 October 2005, New York. New York: United Nations, Department of Economic and Social Affairs. Division for Public Administration and Development Management.

- ZPFOLERD (Transparency of Financial Relations and Maintenance of Separate Accounts for Different Activities Act) $(2007,2008)$ (In Slovene: Zakon o preglednosti finančnih odnosov in ločenem evidentiranju različnih dejavnosti). Official Journal RS, 53/2007, Official Journal RS, 65/2008).

- Zorić, J., Hrovatin, N. (2010): Are Slovenian customers willing to pay for green electricity?. V: 5th International Conference An Enterprise Odyssey: From Crisis to Prosperity Challenges for Government and Business, May 26-29, 2010, Opatija, Croatia. Zagreb: Faculty of Economics \& Business, University of Zagreb, pp. 375-386.

- Zorić, J., Hrovatin, N., Scarsi, G. C. (2009): Gas distribution benchmarking of utilities from Slovenia, the Netherlands and the UK : an application of data envelopment analysis. South East European journal of economics and business, April 2009, vol. 4, no. 1, pp. 113-124 


\section{POVZETEK
KAKO PRIVARČEVATI JAVNA SREDSTVA V SLOVENSKIH JAVNIH PODJETJIH IN PRI INVESTICIJAH V INFRASTRUKTURO?

Namen članka je analizirati, kako uspešna in učinkovita so slovenska javna podjetja pri izvajanju svojih dejavnosti, kakšne so možnosti za prihranke in za pritegnitev tudi zasebnih sredstev $v$ infrastrukturne investicije. Če obstajajo rezerve za znižanje stroškov, lahko javna podjetja dosegajo večji dobiček, iz katerega lahko država prvič, prejema dividende kot proračunski prihodek in drugič, prejema višje davke, saj tudi javna podjetja plačujejo davek na dobiček. Država lahko torej s povečanjem donosnosti javnih podjetij prejme večji proračunski kolač $v$ dveh vlogah, $v$ vlogi lastnika in $v$ fiskalni vlogi. Po drugi strani nižji stroški javnih podjetij omogočajo zniževanje cen proizvodov in storitev, kar lahko na povpraševalni strani deluje spodbujevalno, saj potrošnikom ostaja višji nerazdeljeni dohodek, kar vzpodbuja večje agregatno povpraševanje in s tem gospodarsko rast. Analiza možnih prihrankov temelji na pregledu znanstvenih objav o učinkovitosti in uspešnosti slovenskih javnih podjetij in na analizi ugotovitev pristojnih organov za njihov nadzor (Računskega sodišča).

Za slovenska komunalna podjetja (oskrba z vodo) ter plinska in elektrodistribucijska podjetja so bile izdelane benčmarking analize stroškovne učinkovitosti, ki primerjajo bodisi samo domača podjetja med sabo, bodisi domača podjetja s tujimi $v$ isti panogi z uporabo različnih modelov. Analiza možnih prihrankov je pokazala na precejšnje rezerve za zniževanja stroškov in za posledično povečanje njihove donosnosti. $S$ tem bi se povečali tudi prihodki njihovih lastnikov - države in občin in sicer neposredno $v$ obliki udeležbe $v$ dobičku in $z$ davkom na dohodek podjetij. Primerjalne benčmarking analize plinskih in elektrodistribucijskih podjetjih ter podjetij za oskrbo z vodo so pokazale na možnost $34 \%$ (plinska), $11 \%$ (elektrodistribucijska) oziroma $16 \%$ (podjetja za oskrbo z vodo) znižanja stroškov povprečno letno, če primerjamo samo domača podjetja. Če jih primerjamo s tujimi podjetji, pa so možni prihranki še večji. Del te neučinkovitosti gre prepisati tudi premajhni velikosti podjetij. Že samo z združevanjem podjetij bi lahko realizirali določene stroškovne prihranke. Če upoštevamo, da so analize zajele samo tekoče stroške poslovanja, ne pa tudi stroškov kapitala, bi bili dejanski prihranki ob upoštevanju vseh 
Nevenka Hrovatin

Potentials for savings in the Slovenian public

enterprises and investments in infrastructure?

stroškov lahko še večji. Njihovo učinkovitost bi bilo mogoče povečati tudi z vpeljavo ustrezne regulacije (na primer za podjetja za oskrbo z vodo) oziroma s pridobivanjem izkušenj in znanja regulatorja. Britanski primer plinskih podjetij namreč kaže, da ustaljena, izdelana in daljša regulatorna praksa omogoča bolj učinkovito regulacijo, ki se posledično kaže $v$ večji učinkovitosti podjetij. Analizirana podjetja imajo tudi previsoke stroške dela, saj so se le-ti (na primer v dejavnosti oskrbe z elektriko in plinom) povečevali hitreje od slovenskega povprečja. Poleg tega pa stroški dela zajemajo tudi del stroškov, ki jih regulator ne priznava kot upravičene in zato znižujejo donos podjetij. Na številne pomanjkljivosti, katerih odprava bi zagotovo povzročila zniževanje stroškov, je pri vzdrževanju in gradnji avtocest ter cest in urejanju javnih površin opozorilo tudi Računsko sodišče. Celoten sistem rednega in investicijskega vzdrževanja avtocest v družbi DARS je organiziran tako, da vzpodbuja višjo porabo javnih sredstev in s tem nižjo učinkovitost na račun doseganja višje donosnosti poslovanja družbe $v$ državni lasti DARS in družbe DCC. Računsko sodišče je opozorilo tudi na pomanjkljivosti vzdrževanja občinskih cest $v$ nekaterih slovenskih občinah in na neučinkovitost porabe proračunskih sredstev pri izvajanju obvezne občinske gospodarske javne službe urejanja javnih zelenih površin na podlagi analize za leto 2007. Ker občine določijo le obseg sredstev, ne pa tudi, kako naj se sredstva porabijo in kakšna je zahtevana kakovost, je poraba sredstev prepuščena izvajalcem, nad katerimi ni vzpostavljenega ustreznega nadzora.

Možni dodatni viri za proračunske prihodke so tudi v izkoriščanju pripravljenosti uporabnikov za plačilo določenih proizvodov in storitev (na primer za zeleno energijo). Slovenska država nudi podpore za soproizvodnjo elektrike in toplote z visokim izkoristkom, ki jih zbere iz obveznega prispevka $v$ omrežnini, katerega zavezanci za plačilo so vsi uporabniki električne energije. Takšno zbiranje sredstev bi bilo deloma mogoče nadomestiti z neposrednimi prispevki uporabnikov za zeleno energijo, sredstva podpor, ki se zbirajo preko cene za uporabo omrežij, pa bi lahko preusmerili $v$ trošarine za polnjenje proračunske luknje

Koliko teh sredstev bi lahko nadomestili s prispevki uporabnikov, je seveda odvisno od pripravljenosti slovenskih gospodinjstev za plačilo zelene energije. Raziskava Zorić in Hrovatin o pripravljenosti na plačilo za zeleno energijo iz leta 2008 je na vzorcu 450 slovenskih gospodinjstev ocenila, da je kar $77 \%$ anketiranih gospodinjstev pripravljeno plačati za zeleno energijo in sicer $v$ povprečju 4,2 evra mesečno, kar predstavlja 
10,5\% mesečnega računa za elektriko. Če pa pri izračunu mesečnega zneska upoštevamo samo tiste, ki so pripravljeni plačati za zeleno energijo, pa se znesek povzpne na 5,4 evra. Če upoštevamo, da smo leta 2007 imeli 745.000 gospodinjstev, bi le-ta bila letno pripravljena plačati okrog 37,5 milijona evra za zeleno energijo. Seveda je potrebno pri tem upoštevati, da bi bil ta znesek v resnici nižji, saj je dejanska pripravljenost za plačilo praviloma nižja od hipotetične. Po drugi strani pa bi bilo mogoče pripravljenost za plačilo bolj izobraženih gospodinjstev ter tistih z višjim dohodkom in bolj ekološko osveščenih tudi povečati, saj je ekonometrična analiza $v$ omenjeni raziskavi pokazala, da so takšna gospodinjstva bolj nagnjena k plačilu za zeleno energijo. Na to bi lahko vplivali z ustreznimi trženjskimi strategijami podjetij pa tudi $z$ večjim ozaveščanjem državljanov $\mathrm{s}$ strani ustreznih državnih institucij.

Seveda bi bilo še ugodneje, če ne bi večali trošarin, temveč bi povečali sredstva za vzpodbujanje teh investicij, saj bi to tudi preko zagona povezanih dejavnosti $v$ daljšem obdobju prispevalo $k$ povečanju proračunskih prihodkov (preko davkov in dobičkov). Zaradi vsega povedanega je treba preusmeritev obveznih podpor zbranih preko omrežnin razumeti kot začasen in omejen ukrep $v$ času krize kot pomoč državnemu proračunu, da si čim hitreje opomore.

Razbremenitev občinskih proračunov in državnih garancij pa bi bilo mogoče doseči tudi $z$ večjo pritegnitvijo zasebnega kapitala $v$ financiranje infrastrukturnih investicij. Slovenija je to možnost doslej izkoriščala $v$ zelo omejenem obsegu. $\mathrm{V}$ vseh evropskih projektih javno-zasebnega partnerstva (JZP) je udeležena le z 0,1\% in se skupaj z Dansko, Latvijo in Slovaško uvršča na dno lestvice držav po razvitosti JZP. Na podlagi zakonodajnih sprememb se $v$ Sloveniji tudi povečuje obseg in vloga javne lastnine in to še zlasti na občinski ravni. Podatki o zadolževanju občin kažejo, da je dolg občin leta 2007 obsegal le 2,6\% javnega dolga, vendar le-ta narašča. V letih 2007 - 2009 se je bruto zadolžitev občin povečala skoraj za petkrat, neto zadolžitev pa za 6,6 krat. Na prvem mestu se občine zadolžujejo za izgradnjo šol, vrtcev in športnih dvoran, na drugem mestu pa za izgradnjo komunalne infrastrukture (vodovod, kanalizacija, čistilne naprave), kjer bi lahko v večji meri izkoristile možnosti, ki jih nudi javno-zasebno partnerstvo. O podrazvitosti instrumenta pritegnitve zasebnega kapitala in proračunske razbremenitve zgovorno priča dejstvo, da kar 77 občin $(36,4 \%)$ nima sklenjene nobene pogodbe o javno-zasebnem partnerstvu, kar je 8 več kot $v$ 


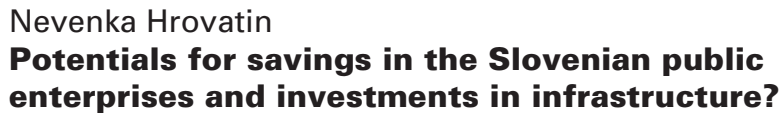

letu 2008. Eno pogodbo ima 49 občin, povprečje na občino pa je 1,95, oziroma, če upoštevamo samo občine, ki imajo sklenjene pogodbe, 3,09.

$\mathrm{Na}$ državni ravni je zadolževanje države in dajanje poroštev za infrastrukturne investicije bolj problematično kot na občinski zaradi večjega obsega. V Evropi je bilo največ JZP ( $60 \%$ po številu in $84 \%$ po vrednosti) $v$ prometu, kjer prevladujejo avtocestni projekti (EIB, 2007). Slovenija možnosti udeležbe zasebnih partnerjev ni izkoristila in je avtocestni križ v celoti gradila z javnimi sredstvi ter dajala poroštva za najetje kreditov javnemu podjetju DARS. Prav ta zajemajo največji delež v strukturi poroštev slovenske države $v$ obdobju 2000-2009 (MF, 2010a), ki so se od 2001 do 2009 povečala od 1,206 milijonov evrov na 4,957 mio evrov, oziroma od 5,8\% BDP na $12,7 \%$ BDP leta 2008 in na $20,5 \%$ leta $2010 .^{\circ}$

Računsko sodišče je opozorilo na zamude pri izgradnji in nedoseganje planirane gradnje $v$ predvidenih časovnih rokih ter na prekoračitve planiranih investicijskih sredstev kot tudi na neustrezno ureditev koncesijskega razmerja in delitve pristojnosti med državo, DARS in družbami za državne ceste. Nevarnosti, ki se napovedujejo pri financiranju avtocestnega programa so tudi $v$ nadaljnjem zadolževanju in problemih $s$ servisiranjem dolga, zato niso presenetljive ocene Računskega sodišča, da bo financiranje izgradnje avtocest trajala dlje od predvidene (2033) in da bo dejansko dokončanje financiranja odmaknjeno na konec sredine tega stoletja (2050) (RSRS, 2009b in Hrovatin, 2010).

$\mathrm{Na}$ državni ravni je zadolževanje države in dajanje poroštev za infrastrukturne investicije bolj problematično kot na občinski zaradi večjega obsega. Čeprav se državna poroštva formalno ne štejejo $v$ javni dolg, predstavljajo potencialno možnost, da se prelijejo $v$ javni dolg, če se poroštva unovčijo. V Evropi je bilo največ JZP $(60 \%$ po številu in $84 \%$ po vrednosti) v prometu, kjer prevladujejo avtocestni projekti. Slovenija možnosti udeležbe zasebnih partnerjev ni izkoristila in je avtocestni križ v celoti gradila z javnimi sredstvi ter dajala poroštva za najetje kreditov javnemu podjetju DARS. Prav ta zajemajo največji delež $v$ strukturi poroštev slovenske države $v$ obdobju 2000-2009, ki so se od 2001 do 2009 povečala od 1,206 milijonov evrov na 4,957 mio evrov, oziroma od 5,8\% BDP na $12,7 \%$ BDP leta 2008 in na 20,5\% leta 2010.

9 Veliko povečanje poroštev leta 2010 izvira predvsem iz poroštev iz naslova reševanja finančne krize in ni povezano z infrastrukturnimi investicijami. 
Računsko sodišče je opozorilo na zamude pri izgradnji in nedoseganje planirane gradnje $v$ predvidenih časovnih rokih ter na prekoračitve planiranih investicijskih sredstev kot tudi na neustrezno ureditev koncesijskega razmerja in delitve pristojnosti med državo, DARS in družbami za državne ceste. Nevarnosti, ki se napovedujejo pri financiranju avtocestnega programa, so tudi $v$ nadaljnjem zadolževanju in problemih s servisiranjem dolga, zato niso presenetljive ocene Računskega sodišča, da bo financiranje izgradnje avtocest trajalo dlje od predvidene (leto 2033) in da bo dejansko dokončanje financiranja odmaknjeno na konec sredine tega stoletja (do 2050).

Ugotovljenih možnih prihrankov slovenskih podjetij ni mogoče doseči brez učinkovitega upravljanja javnih podjetij. Da bi to dosegli, bi v Sloveniji morali uvesti vsaj dve reformi: prvič, uvesti sistem pogodb med državo in javnimi podjetji o doseganju vnaprej določenih ciljev javnih podjetij in drugič, vzpostaviti politično neodvisen sistem kadrovanja menedžerjev na podlagi strokovnih referenc ter sistem nagrajevanja menedžerjev, vezan na rezultate poslovanja javnih podjetij oziroma na preverjanje doseganja vnaprej postavljenih pogodbenih ciljev med državo in javnim podjetjem. 